\title{
Socio-Economic Background of Women Entrepreneurs in Ananthapuramu District
}

\author{
Dr Madhavi Putta ${ }^{1}$, Prof G. Satyanarayana ${ }^{2}$ \\ ${ }^{I}$ Department of Economics, Sri Krishnadevaraya University,Ananthapuramu-515003, A.P., India \\ ${ }^{2}$ Professor of Economics, Dean Social Sciences, Sri Krishnadevaraya University, \\ Ananthapuramu-515003, A.P., India
}

\begin{abstract}
Women Entrepreneurs are slowly coming out of their home to earn something for the sustenance of their families, as the earnings of single individual is not sufficient and becoming entrepreneurs. An attempt is made to study the socio-economic life of sample women entrepreneurs in the Ananthapuramu district in Andhra Pradesh. As a part of socio-economic background - analysis, the age, caste, educational level, debt position, type of family, size of family were considered and responses are analyzed.

Keywords - women entrepreneurs, sustenance, backward district, socio economic conditions, case study

\section{INTRODUCTION}

Entrepreneurship is gaining increasing respect from the scholars as a field of research as well as practical application worldwide as a means to achieve wealth creation and personal fulfillment. History has proven that with each economic downturn, it is the entrepreneurial drive and persistence that brings us back. Entrepreneurship is the capacity in an individual to innovate, to bear risks, to foresee the prospects of the project, confidence and competence to meet unforeseen and adverse conditions. The activities of entrepreneurs are crucial to the economic growth and prosperity of modern societies. Entrepreneurship is a mindset that assigns different values to resources and opportunities than does the general population and a mindset that encourages creativity and innovation, changing the game, and being unique.

Entrepreneurs are examined from various perspectives, such as attitudes, backgrounds, personality traits, economic factors, contextual circumstances, and aspect of social and financial marginality, gender, and geographical location. But there is no unified, generally accepted definition and model of entrepreneurial activity and development. An attempt is made to study the socio-economic life of sample women entrepreneurs in the Ananthapuramu district in Andhra Pradesh.
\end{abstract}

\section{Rational Behind Sample Selection}

Ananthapuramu district is the most backward and drought ridden district in Andhra Pradesh. Large number of people in the district was either directly or indirectly dependent on agriculture and allied actives. It is often result in the self immolation of marginal, small and other farmers. Under these circumstances the life of women is jeopardizing day to day. The women slowly coming out of their home to earn something for the sustenance of their families, as the earnings of single individual is not sufficient. As the agriculture is not beneficial to run the family, the women are slowly turning their attention to start micro, small enterprises. Most of these enterprises are located in three towns namely Rayadurg, Dharmavaram and Hindupur. Women from other parts of the district are also migrating to these areas as entrepreneurs or for the sake of employment. Hence these three towns were selected for the present study of the Socio-economic background of women entrepreneurs.

\subsection{Profile of Dharmavaram}

Silk industry in Dharmavaram region is an important agro-based, labour-intensive, export-oriented cottage industry. The industry consists of mulberry cultivation, silkworm rearing, reeling, twisting, dyeing, weaving and trading which are inseparable links as a chain. Dharmavaram is predominantly a weaver's centre. The most effective and characteristic cloth is one with a white ground of white' check pattern, crimson borders and brocade ends, sometimes figures of flowers, birds, etc. However due to severe competition from machine made cotton goods, in the early part of this century the erstwhile cotton weavers converted themselves to silk weaving. They produced both male and female wear, jackets, turbans, handkerchiefs and rumals. Products were mainly exported to Gooty, Ananthapuramu, Hindupur, Penukonda and Bangalore. 


\subsection{Profile of Hindupur}

Hindupur is also famous centre for the production of high quality silk yarns. It is an industrial city, a major business centre, and well connected by railways. There are three spinning mills. Hindupur is also famous for Mudireddy Palli silk sarees. These sarees are made out of cheap silk. But the sarees looks like Kanchipuram Sarees. Most nationalized banks have branches in Hindupur.

\subsection{Profile of Rayadurg}

The areas surrounding Rayadurg are famous for high quality Groundnut, Tamarind and Custard Apple (Seethaphal). A special variety of Pomegranate and Brinjal can be seen here throughout the year. Weaving silk and cotton saris, Garment industry and farming are the main sources of revenue. Nearly 20,000 people are working in garment units. Rayadurg has one of the biggest garment industries in South India, exporting garments worth Rs. 200 crores per annum. Jeans, cargos, full shirts were very famous in this area. These are available in cheap prices. It is connected through railways to other parts such as Bellary, Chitradurga and Bangalore. The first meter gauge line was laid in 1906 from Bellary (Karnataka) to Rayadurg (Andhra Pradesh).

\section{Socio-Economic Background Of Women Entrepreneurs}

As a part of socio- economic background analysis, the age, religion, sub-caste, educational level, debt position, type of family, size of family were considered and responses are analyzed.

\subsection{Caste of Sample Respondents}

The Ananthapuramu district is predominantly inhabited by Backward Castes, Scheduled Castes, Scheduled Tribes and other non-reserved category people. But large number of enterprises is owned by nonreserved castes. Table 1 gives the details of social stratification of sample respondents in three sample Mandal areas. As per the Table 1, nearly 46.67 percent sample women entrepreneurs in the study area belong to non reserved categories. They are followed by backward class entrepreneurs with 39 percent. The scheduled castes and Scheduled Tribes together constitute 14.33 percent of total entrepreneurs. To be precise 5 percent are Scheduled Tribes and 9.33 percent are Scheduled Castes. There are no major variations among selected towns or stations.

Table 1: Caste-Wise Distribution

\begin{tabular}{|c|c|c|c|c|c|}
\hline \multirow{2}{*}{ S. No } & \multirow{2}{*}{ Caste } & \multicolumn{2}{|c|}{ Locality Wise Coverage of Entrepreneurs } & \multirow{2}{*}{ Total (\%) } \\
\cline { 3 - 5 } & & Rayadurg & Dharmavaram & Hindupur & \\
\hline 1 & Scheduled Tribes & 5 & 4 & 6 & $15(5.00)$ \\
\hline 2 & Scheduled Caste & 11 & 9 & 8 & $28(9.33)$ \\
\hline 3 & Backward Classes & 37 & 41 & 39 & $117(39.00)$ \\
\hline 4 & Others & 47 & 46 & 47 & $140(46.67)$ \\
\hline \multicolumn{2}{r|}{ Grand Total } & $\mathbf{1 0 0}$ & $\mathbf{1 0 0}$ & $\mathbf{1 0 0}$ & $\mathbf{3 0 0}$ \\
\hline
\end{tabular}

Source: Field Survey

\subsection{Types of family}

The type of the family in which women is living influences her life style. As such during field survey the family particulars of sample women entrepreneurs is registered and presented in the table 2 . As per the field data the sample women entrepreneurs are living in three types of families such as (i) Nuclear family, (ii) Joint family, and (iii) Extended family.

Table 2: Type of family

\begin{tabular}{|c|c|c|c|c|c|}
\hline \multirow{2}{*}{ S. No } & \multirow{2}{*}{ Type of Family } & \multicolumn{2}{|c|}{ Locality Wise Coverage of Entrepreneurs } & \multirow{2}{*}{ Total (\%) } \\
\cline { 3 - 5 } & Nuclear Family & Rayadurg & Dharmavaram & Hindupur & \\
\hline 1 & 84 & 88 & 89 & $261(87.00)$ \\
\hline 2 & Joint Family & 13 & 10 & 9 & $32(10.67)$ \\
\hline 3 & Extended Family & 3 & 2 & 2 & $7(2.33)$ \\
\hline & Total & $\mathbf{1 0 0}$ & $\mathbf{1 0 0}$ & $\mathbf{1 0 0}$ & $\mathbf{3 0 0}$ \\
\hline
\end{tabular}

Source: Field Survey

A close observation of table 2 reveals that nearly 87 percent of the respondents are living in nuclear families. Nearly 89 percent of Hindupur town entrepreneurs are living in nuclear families and they top the list in this regard. They are immediately followed by Dharmavaram women entrepreneurs with 88 percent and Rayadurg with 84 percent. In case of joint families Rayadurg entrepreneurs with 13 families stood at the top of 
the ladder. Among the Hindupur entrepreneurs 10 families and Dharmavaram 9 families are of Joint families. In case of extended families Rayadurg tops the list with three families and they are followed by Dharmavaram and Hindupur women entrepreneurs with equal number. In all 87 percent of families are nuclear families, about 10.67 percent of the families are joint families. The table 2 revels that only 7 out of 300 families that is just 2.33 percent are the extended families.

\subsection{Size of the Family}

Family is one of the basic institutions of the society. The number of earning members in the family determines the standard of living of the family. Table 3 exhibits the particulars of family size of the selected sample entrepreneurs in the study area.

Table 3: Size of the Family

\begin{tabular}{|c|c|c|c|c|c|}
\hline \multirow{2}{*}{$\begin{array}{c}\text { S. } \\
\text { No }\end{array}$} & \multirow{2}{*}{ Number of Members } & \multicolumn{3}{|c|}{ Locality Wise Coverage of Entrepreneurs } & \multirow{2}{*}{ Total $(\%)$} \\
\hline & & Rayadurg & Dharmavaram & Hindupur & \\
\hline 1 & Less than 5 members & 88 & 89 & 91 & $268(89.33)$ \\
\hline 2 & 6 to 8 members & 9 & 8 & 7 & $24(8.00)$ \\
\hline 3 & 9\&above & 3 & 3 & 2 & $8(2.67)$ \\
\hline & Total & 100 & 100 & 100 & 300 \\
\hline
\end{tabular}

Source: Field Survey

As per table 3, the family size of 91 percent of Hindupur entrepreneur's family size is less than 5 members. In case of Dharmavaram and Rayadurg entrepreneurs 89 percent and 88 percent of the entrepreneurs family size is also less than five members. The family size of 9 Rayadurg entrepreneurs, 8 Dharmavaram entrepreneurs and 7 Hindupur entrepreneurs ranges between 6 and 8. With regard to Rayadurg and Dharmavaram equal number (3) of entrepreneurs family size is nine and above. In case of Hindupur only 2 entrepreneurs family size is 9 and above. In all 89.33 percent entrepreneur's family size in the study area is less than five members. Nearly 8.00 percent of entrepreneur's family size is 6 to 8 members. The size of 2.67 percent of entrepreneurs is very large family consisting more than 9 members.

\subsection{Age group of Entrepreneurs}

The earnings and other economic activities of an individual largely depend on the age of respective individual. As such during field survey the age particulars sample entrepreneurs is registered and the same is presented in the table 4.

Table 4: Age Wise distribution

\begin{tabular}{|c|c|c|c|c|c|}
\hline \multirow{2}{*}{ S. No } & \multirow{2}{*}{ Age Group } & \multicolumn{3}{|c|}{ Locality Wise Coverage of Entrepreneurs } & \multirow{2}{*}{ Total $(\%)$} \\
\hline & & Rayadurg & Dharmavaram & Hindupur & \\
\hline 1 & Below 35 years & 23 & 15 & 11 & 49 (16.33) \\
\hline 2 & $36-45$ years & 35 & 36 & 19 & $90(30.00)$ \\
\hline 3 & $46-60$ years & 31 & 31 & 51 & $113(37.67)$ \\
\hline 4 & 61 and above & 11 & 18 & 19 & $48(16.00)$ \\
\hline & Grand Total & 100 & 100 & 100 & 300 \\
\hline
\end{tabular}

Source: Field Survey

It can be inferred from table 4 that the Rayadurg with 23 entrepreneurs tops the list in case of below 35 years age group. In this age group they are followed by Dharmavaram and Hindupur with 15 and 11 entrepreneurs, who stood at second and third places. But, in case of second age group of 36-45 years Dharmavaram stood at the top of the rung with 36 percent entrepreneurs hailing from that group. It is immediately followed by Rayadurg and Hindupur with 35 percent and 19 percent respectively. The third age group (46-60 years) entrepreneurs are high in case of Hindupur. More than half of the entrepreneurs of this locality are in this age group. In this case, Hindupur entrepreneurs are followed by Rayadurg and Dharmavaram entrepreneurs with 31 per cent each. In case of fourth age group of 61 and above years the Hindupur entrepreneurs again tops the list with 19 percent. It is immediately followed by Dharmavaram and Rayadurg entrepreneurs in second and third places. In all, Dharmavaram is dominating in case of second age group of 3645 years. On the other hand, Hindupur entrepreneurs have their edge in case of 46-60 years and 51 and above age groups. The Rayadurg entrepreneurs are dominating the below 35 years age group. 


\subsection{Education Levels Sample Entrepreneurs}

Now-a-days education is considered as a tool for socio-economic development and for active participation in political field. In Indian society, the women kept aloof from education system until recently. So, during the field survey, the educational levels of sample women entrepreneurs are registered and presented in the table 5 .

Table 5: Educational Status

\begin{tabular}{|c|c|c|c|c|c|}
\hline \multirow{2}{*}{ S. No } & \multirow{2}{*}{ Education } & \multicolumn{2}{|c|}{ Locality Wise Coverage of Entrepreneurs } & \multirow{2}{*}{ Total (\%) } \\
\cline { 3 - 6 } & & Rayadurg & Dharmavaram & Hindupur & \\
\hline 1 & Primary School & 11 & 14 & 10 & $35(11.67)$ \\
\hline 2 & Upper-Primary School & 15 & 16 & 18 & $49(16.33)$ \\
\hline 3 & High School & 29 & 27 & 25 & $81(27.00)$ \\
\hline 4 & Intermediate & 28 & 27 & 28 & $83(27.67)$ \\
\hline 5 & Degree and above & 14 & 9 & 11 & $34(11.33)$ \\
\hline 6 & Professional Degree & 3 & 7 & 8 & $18(6.00)$ \\
\hline \multicolumn{7}{|c|}{ Grand Total } & $\mathbf{1 0 0}$ & $\mathbf{1 0 0}$ & $\mathbf{1 0 0}$ & $\mathbf{3 0 0}$ \\
\hline
\end{tabular}

Source: Field Survey

From table 5, it is observed that 11.67 percent of entrepreneurs have access to primary education. About 16.33 percent of the entrepreneurs studied up to $7^{\text {th }}$ class. The entrepreneurs who have access to high schools constitute 27 percent. Nearly 27.67 percent of entrepreneurs have entered to college level education i.e. intermediate. Those who have access to Degree level and above education constitute 11.33 percent of total entrepreneurs. Only 18 out of 300 entrepreneurs are possessing professional degree. There are no large variations across the localities.

\section{Economic Conditions of Women Entrepreneurs}

The proper running of enterprise largely depends on the economic conditions, under which a family is living. The poor economic background leads to lockout of enterprises. As such during field survey the economic conditions of entrepreneurs were registered and presented in the following table. An enterprise could be run successfully only when the entrepreneurs are not trapped in debts. Further, it can be understood that if the entrepreneurs are drowning in debts, financial help rendered by financial institutions may be misused by the entrepreneurs. As such, during field survey the debt position of women respondent families was recorded and presented in table 6.

Table 6: Debt Position

\begin{tabular}{|c|c|c|c|c|c|}
\hline \multirow{2}{*}{ S. No } & \multirow{2}{*}{ Debt (Rs.) } & \multicolumn{3}{|c|}{ Locality Wise Coverage of Entrepreneurs } & \multirow{2}{*}{ Total $(\%)$} \\
\hline & & Rayadurg & Dharmavaram & Hindupur & \\
\hline 1 & No debts & 11 & 15 & 15 & $41(13.66)$ \\
\hline 2 & Below 100,000 & 36 & 51 & 47 & $134(44.67)$ \\
\hline 3 & 100001 to 200000 & 43 & 25 & 22 & $90(30.00)$ \\
\hline 4 & 200001 to 400000 & 5 & 6 & 9 & $20(6.67)$ \\
\hline 5 & 400001 and above & 5 & 3 & 7 & $15(5.00)$ \\
\hline & Total & 100 & 100 & 100 & 300 \\
\hline
\end{tabular}

Source: Field Survey

It is crystal clear from table 6 that 86.34 percent of the sample entrepreneurs are in debts with varying amounts. The debt amount of 44.67 percent of the entrepreneurs is below Rs.100,000. Those who have debts between Rs.100,000 and Rs.200,000 constitute 30 percent of total entrepreneurs. The debt amount of 6.67 percent of entrepreneurs is above Rs.200,000 and below Rs.400,001. It can be further noticed that the debt amount of 5 percent of entrepreneurs is Rs.400001 and above. Only 41 out of 300 entrepreneurs constituting 13.66 percent have no debts.

In case of no debts Dharmavaram and Hindupur entrepreneurs with 15 each tops the list and they are followed by Rayadurg with 11 entrepreneurs. The debt position of 51 Dharmavaram entrepreneurs is below Rs.100, 000. In this debt group, they are followed by Hindupur and Rayadurg women with 47 and 36 percent respectively. In case of debt group of Rs.100, 001 to Rs.200, 000 Rayadurg women tops the list with 43 percent and they are followed by Dharmavaram and Hindupur women with 25 percent and 22 percent respectively. With 
regard to Rs.200,001 to Rs.400,000 debt group the Hindupur women tops the list with 9 percent. They are followed by Dharmavaram and Rayadurg women in second and third places. It is clearly visible in the figure 1.

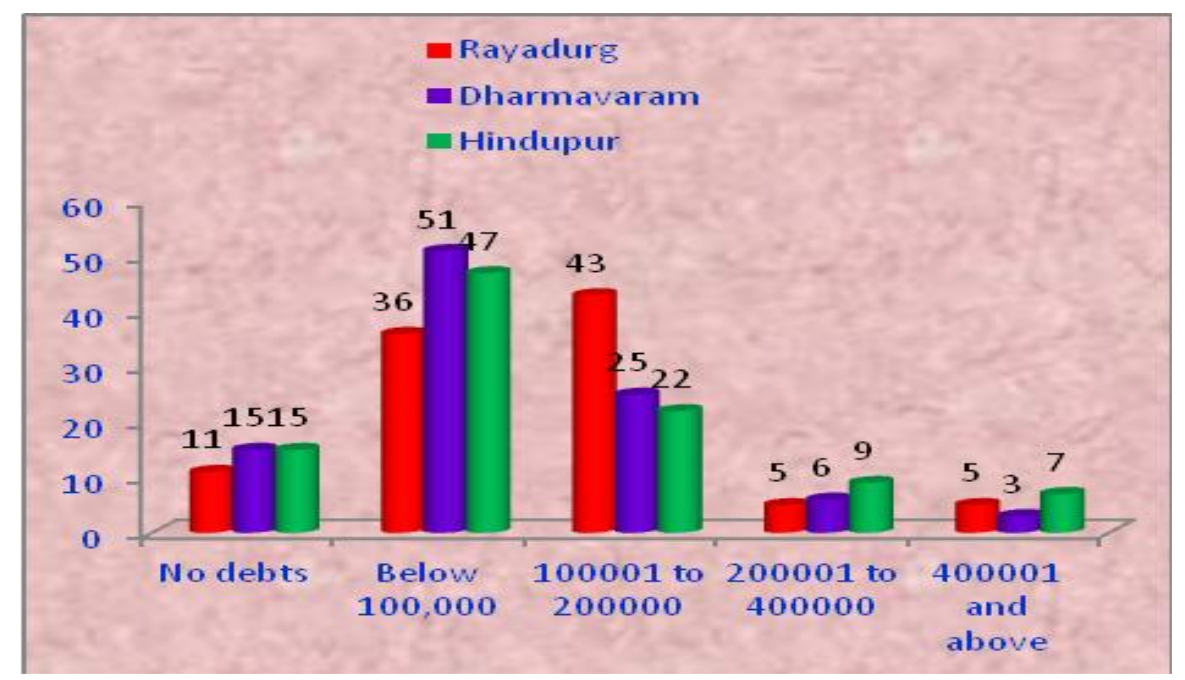

Fig.1: Debt Position of Sample Women Entrepreneurs

\section{Conclusions}

It is important to note that most of the women entrepreneurs in the study area belong to non-reserved category. The Scheduled Castes and Scheduled Tribes together constitute only 14.33 percent of total entrepreneurs. Highest percentage of women entrepreneurs are in the age group of 46 to 60 years. The percentage of women graduates is less than 12 percent. Those who possess professional degree are confined to 6 percent. It is pertinent to note that nearly 87 percent have some amount of debts. The study reveals that the educated women are to be attracted towards entrepreneurship.

\section{References}

[1]. Singh, Kamala, Women Entrepreneurs, Ashish Publishing House, New Delhi, 1992

[2]. Kamalanathan, Godavari, "Empowering, Mobilizing Women at Gross Roots: Role of NGOS", The Indian Journal of Home Science, Vol.23, Nos.1\&2, 1994, pp.87.

[3]. Gopalan, Sarala, "Paradigm Shift: From Welfare to Empowerment", Social Welfare, Vol.43, No.5, 1996, pp.33.

[4]. Biplab, Moitra, "Women and Entrepreneurship: "Suburban Women Show the Way", Kurukshetra, Vol.49, 2001, pp.28-30.

[5]. Valamathi, A., "Challanges to Entrepreneurial Development of Women in India", The Economic Challenger, Lata Khothari, Ajmeer, 2010, pp.40-43.

[6]. Ray Sarbapriya1, Aditya Ray Ishita, "Some Aspects of Women Entrepreneurship in India” Asian Journal of Management Research, Vol. 2, Issue 1, 2011, pp.1-13.

[7]. Vasantha Kumari, "Economic Empowerment of Women through Micro Enterprises in India with Special Reference to Promotional Agencies", International Journal of Multidisciplinary Research, Vol.2, No.1, 2012, pp. 194-210.

[8]. Madhavi P, Appa Rao N, Satyanarayana G, "Self-confidence of Women Entrepreneurs - A Case Study of a Backward District", Paripex - Indian Journal of Research, Vol.2, No.3, 2013, pp.64-65.

[9]. Altering the name of Anantapur district as "Ananthapuramu District", Government of Andhra Pradesh, G.O.Ms.No.187, dated 10 th April, 2013. 